Menzie D. Chinn

William F. Maloney

Working Paper 5814

NATIONAL BUREAU OF ECONOMIC RESEARCH

1050 Massachusetts Avenue

Cambridge, MA 02138

November 1996

We thank Chris Erceg, John Fernald, Ramon Moreno and Clifford Tan for useful discussions, Ramon Moreno and Carlton Strong for data, and Eduardo Ribeiro for research assistance. We also gratefully acknowledge financial support from UCSC divisional research grants (Chinn) and the University of Illinois Research Board (Maloney). This paper is part of NBER's research program in International Finance and Macroeconomics. Any opinions expressed are those of the authors and not those of the National Bureau of Economic Research.

(C) 1996 by Menzie D. Chinn and William F. Maloney. All rights reserved. Short sections of text, not to exceed two paragraphs, may be quoted without explicit permission provided that full credit,

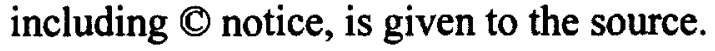




\title{
FINANCIAL AND CAPITAL ACCOUNT LIBERALIZATION IN THE PACIFIC BASIN: KOREA AND TAIWAN DURING THE 1980'S
}

\begin{abstract}
This paper presents an alternative method of testing for financial capital mobility in the absence of forward exchange markets. A model of domestic interest rate determination during liberalization is applied to Korean and Taiwanese data. A variety of diagnostic and recursive tests are used to isolate structural breaks in the data. It is shown that Korean interest rates behave as if determined domestically until late 1988 or early 1989 , while Taiwanese rates exhibit this behavior until early 1989. Thereafter, these economies' interest rates appear tightly linked to the EuroYen rate. These results contrast with those obtained by Reisen and Yèches (1993) which indicated a single opening and closing for Korea, and no structural break for Taiwan. They also differ from those results of Jwa (1994) indicating two temporary openings for Korea. Greater integration of these domestic markets with world financial markets suggests that it will be more difficult for these countries to stabilize their economies in the face of capital inflows and outflows.
\end{abstract}

Menzie D. Chinn

Department of Economics

University of California

Santa Cruz, CA 95064

and NBER

chinn@cats.ucsc.edu
William F. Maloney

Department of Economics

University of Illinois

Urbana, IL 61801

wmaloney@ux6.cso.uiuc.edu 


\section{INTRODUCTION}

There is by now a great deal of evidence pointing to increasing financial capital mobility around the Pacific Rim. The most common measure of this integration is the extent to which covered interest parity (CIP) holds: In the absence of regulatory barriers to arbitrage, similar assets should yield similar returns across countries when adjusted for the risk of currency depreciation embodied in the forward discount. Hence the reduction of the covered interest differential has often been used as a test of capital account liberalization.' Yet, for a majority of countries that are liberalizing, or contemplating liberalization, forward markets are either extremely thin or non-existent, rendering covered interest parity tests irrelevant and making it difficult to judge the economic impact of capital account and financial sector liberalization with any degree of certainty.

This constraint has been particularly frustrating in the cases of Taiwan and Korea, two countries which despite substantial (albeit intermittent) efforts toward freeing capital flows, show little evidence of increasing integration in the world financial capital markets. Chinn and Frankel (1994b), using interest rates unadjusted for expected depreciation, find mixed evidence of increased comovement between domestic and US interest rates over the 1982-1992 period, but no significant evidence of increasing integration according to an uncovered interest parity condition. Perhaps the most ambitious and empirically sophisticated assessments, conducted by Reisen and Yèches (1993), Jwa (1994) and Dooley and Mathieson (1994), employ a now popular technique introduced by Edwards and Khan (1985). This technique involves a regression of

${ }^{1}$ See Chinn and Frankel (1994a) for several Pacific Basin countries. This approach equates the capital account opening with the elimination of what Aliber (1973) termed "political risk". 
money balances on a (counterfactual) closed economy interest rate and a foreign interest rate, and the interpretation of the weight on the foreign interest rate as a measure of openness. ${ }^{2}$ Corroborating the results of previous studies, Reisen and Yèches conclude that "Official liberalization measures undertaken in Korea and Taiwan during the 1980's have thus largely failed to strengthen interest links with the rest of the world. The capital account of both countries seems still quite closed with the possible exception of Taiwan's interbank market in very recent years" (p.304). ${ }^{3}$

This paper examines essentially the same period as previous studies for Korea and Taiwan but employs a technique that extracts information from the behavior of the coefficients on the domestic determinants of interest rates; as a capital account opens, it is expected that these coefficients should decrease in importance. To specify the channels though which foreign capital flows influence domestic returns and the coefficients on these domestic determinants, we work in the context of a portfolio balance model developed in Maloney (forthcoming) and based on earlier work by Kouri and Porter (1974). This approach seems more attractive than the previous ones for two reasons. First, the model suggests that the coefficient of openness approach employed by previous researchers does not account for some potentially important issues of simultaneity, and hence casts some doubt on their conclusion that there has been no opening. Second, the modelling approach appears to work well. Using the implied semi-reduced form

\footnotetext{
${ }^{2}$ If the foreign coefficient enters in significantly, and the local rate provides little additional information, then the country is considered "open".

${ }^{3}$ Notice that all these studies refer to the mobility of financial capital. We leave aside issues of physical capital mobility, as investigated by Kim (1993). He finds no evidence of structural breaks in Feldstein and Horioka style savings investment correlations during the 1980's.
} 
specification on Japanese data, Maloney was able to identify the same structural break points as those indicated by the disappearance of the covered interest differential. Thus, on both theoretical and empirical grounds this technique appears to offer a reliable way to test for structural breaks when forward rates are absent.

Our results indicate that both Korea and Taiwan experienced structural breaks in their interest rate determination equations in the late 1980 's. We therefore offer a more optimistic view of the consequences of their liberalization efforts. In Korea, recursive tests show the foreign rate of return clearly gaining a heightened importance in late 1988 or early 1989 and domestic factors losing a commensurate amount of influence, suggesting a greater openness to world capital markets. The break for Taiwan in early 1989 is more difficult to interpret due to the inability to correlate it with any particular liberalization measures and dramatic changes in central bank policy occurring at that time. However, domestic interest rates in the post-break period are cointegrated with the EuroYen rate. Hence, overall the evidence points to a greater degree of openness after the break.

The paper is organized as follows. In section 2 , the theoretical model is outlined, while in section 3, the data and econometric methodology are described. Section 4 reports the empirical results. Section 5 concludes.

\section{MODELING A LIBERALIzING CAPITAL ACCOUNT}

\subsection{PREVIOUS LITERATURE}

The general approach of measuring of openness by examining the relative influence of foreign and domestic interest rates was pioneered by Edwards and Khan (1985) and Edwards 
(1986). Their model takes the interest rates that would prevail under the two polar cases represented by a closed economy interest rate determination model $\left(R^{\prime}\right)$ and the interest parity condition $\left(R^{*}\right)$ and then weights them using a "coefficient of openness," $\varphi$.

$$
R=\varphi R^{*}+(1-\varphi) R^{\prime}
$$

A semi-reduced form equation can be derived for the domestic interest rate in terms of income, the real money supply, and the foreign return which, when estimated, permits $\varphi$ to be recovered. Building on this basic framework, Haque and Montiel (1990) derived coefficients of openness by estimating equations for money demand equations rather than for the domestic interest rate.

One objection to this approach is that it is does not make clear how the implicit averaging of closed and open economy interest rates arises from the behavior of individuals in the economy. Within a portfolio balance framework one can derive a semi-reduced form for interest rates that differs critically from that of the Edwards and Kahn tradition.

\subsection{A PORTFOLIO BALANCE MODEL ${ }^{4}$}

In a simple open economy domestic agents can hold four assets in their portfolios: Money (M), Domestic Bonds (B) paying a return $R$, a foreign bond $(F)$ paying $R^{*}$, a nominal interest rate plus expectations of depreciation, and an asset, perhaps land (L), effectively indexed to inflation $(\pi)$. Then money demand is a function of economic activity, home and foreign interest rates, expected inflation, and wealth. Expressing money demand in changes, monetary equilibrium requires that

\footnotetext{
${ }^{4}$ This is an abbreviated version of the discussion in Maloney (forthcoming).
} 


$$
\Delta M\left(Y, R, R^{*}, \pi^{e}, W\right)=\Delta D C+C A+K A
$$

where DC is domestic credit, and CA and KA, the current and capital accounts respectively, reflect the reserve component of the money supply. It is assumed, for expositional purposes, that the money multiplier is unity. The capital account can be viewed as the change in foreign demand for domestic assets, represented by an analogous demand function (where * indicates the foreign country) minus the change in domestic demand for foreign assets:

$$
K A=\Delta B^{*}\left(Y^{*}, R, R^{*}, \pi^{e *}, W^{*}\right)-\Delta F\left(Y, R, R^{*}, \pi^{e}, W\right)
$$

Combining (2) and (3), expanding the asset demands around their arguments, and then invoking wealth constraint to solve for the change in the domestic interest rate (with the second order foreign arguments dropped) yields a semi-reduced form equation:

$$
\Delta R=\beta_{1} \Delta D C+\beta_{2} C A+\beta_{3} \Delta Y+\beta_{4} \Delta \pi^{e}+\beta_{5} \Delta W+\beta_{6} \Delta R^{*}
$$

where

$$
\begin{gathered}
\beta_{1}, \beta_{2}=\frac{1}{\theta} \quad \beta_{3}=\frac{L_{y}+B_{y}}{\theta} \quad \beta_{4}=\frac{L_{\pi}+B_{\pi}}{\theta} \quad \beta_{5}=\frac{L_{w}+B_{w}}{\theta} \\
\beta_{6}=\frac{B(\lambda)_{R^{*}}+B(\lambda)_{R^{*}}^{*}}{\theta} \quad \theta=-\left[L_{R}+B(\lambda)_{R}+B(\lambda)_{R}^{*}\right] \\
B_{R^{*}}, B_{R^{*}}^{*} L_{m} B_{p} B_{\pi}<0 ; B_{R^{\prime}} B_{R}^{*}, L_{\pi}, L_{w}, B_{W}>0
\end{gathered}
$$

Here, $\lambda$ represents the degree of openness of the capital account which is the key determinant of the magnitude of substitutability between domestic and foreign bonds as represented by the four domestic and foreign partial derivatives. These in turn determine the value of each coefficient in (4). In an entirely closed economy with $\lambda=0$, there is no substitution between 
domestic and foreign assets so both $B_{R^{*}}$ and $B_{R}{ }_{R}$ equal 0 , making $\theta$ finite and $\beta_{6}=0$. This leaves an expression similar to a Fisher equation, where expectations of inflation affect the interest rate while the nominal return on foreign assets and expectations of depreciation do not.

As $\lambda$ rises and domestic and foreign bonds become more and more substitutable, $B_{R}$ and $\mathrm{B}_{\mathrm{R}}{ }_{\mathrm{R}} \rightarrow \infty$ and $\mathrm{B}_{\mathrm{R}^{*}}$ and $\mathrm{B}_{\mathrm{R}^{*}} \rightarrow-\infty$, forcing $\theta$ to infinity, all coefficients with finite numerators, $\beta_{1}$ to 5 , go to zero, and $\beta_{6}$ to unity. The intuition is straightforward. Any domestic factor that might increase the interest rate--a contraction of domestic credit, an increase in demand for transaction balances, or an increase in expectations of inflation--leads to an immediate capital inflow that forces the interest rate back to the world rate. The return to foreign bonds inclusive of expectations of depreciation completely determines movements in domestic interest rates, as in the standard uncovered interest parity condition.

Equation (4) differs from that estimated by Kahn and Edwards by excluding the endogenously determined capital account contribution to the money supply. This difference is critical. Inspection of equation (4) suggests that inclusion of $\Delta \mathrm{M}$ instead of the sum of $\mathrm{CA}+$ $\triangle \mathrm{DC}$ implicitly controls for capital inflows, when one actually wishes the capital inflows to be free to vary, and hence influence the domestic interest rate. In other words, changes in the money stock due to capital inflows are a critical channel of influence from the international to the domestic economy: A fall in the world rate leads to a capital inflow which expands the money stock and forces down domestic rates. Hence, it is probably not "openness" that $\varphi$ is measuring, but perhaps the ease of reallocation of portfolios when asset stocks are fixed, i.e., when the capital account is closed. Moreover, theoretically there should be no structural break in the estimated relationship during liberalization unless this ease of reallocation is also affected. By 
contrast, testing for structural break in equation (4) can give us information on whether liberalization measures have in fact led to greater financial capital mobility.

\section{DATA AND METHODOLOGY}

\subsection{DESCRIPTION OF DATA}

The variables of relevance, as indicated by equation (4), include interest rates, domestic credit and income (both entered in the regression in log terms), the current account, expected inflation, wealth, and an expected foreign rate of return. Some of these variables -- expected inflation and the expected foreign rate of return -- are unobservable because they incorporate market expectations. For the former, we use either the ex post value as a rational expectations assumption would dictate, or lagged values (i.e., assuming adaptive expectations). The second unobservable, the expected foreign return, is composed of the foreign return, denominated in foreign currency units, and an expected change in relative currency values. We impose the assumption that expected changes in exchange rates are zero, so that the foreign rate of interest is used as a proxy for the relevant variable. ${ }^{5}$

Income and current account data are not available at the monthly frequency, so we use industrial production and the trade balance, respectively, as proxies. Since there are no adequate proxies for wealth, this variable is omitted from the analysis.

${ }^{5}$ This is equivalent to assuming that the nominal exchange rate follows a random walk. A similar assumption was made in Faruqee (1992). We also attempted proxying the foreign return with the US interest rate adjusted by expected depreciation. The expected depreciation was modeled as either (i) the ex post depreciation, or (ii) the implied depreciation using a forecast from a rolling ARIMA(0,1,0). In neither case did the foreign return show up significantly, nor was a structural break apparent. This result appears to be a reflection of the well-documented stylized fact that at short horizons, most of the movements in exchange rates are unanticipated. 
The data are drawn from a variety of sources. The principal foreign rate of return is measured by a 3 month EuroYen CD rate, although the EuroDollar rate and LIBOR are also tested for robustness. ${ }^{6}$ Data Resources, Inc. The Korean explanatory variables (domestic credit, the trade balance, industrial production and consumer price inflation) are drawn from the IMF's International Financial Statistics database. The corresponding Taiwanese variables are drawn mainly from the Bank of China's Financial Statistics Monthly and Financial Statistics with the exception of the CPI which was provided by the Federal Reserve Bank of San Francisco database.

The key variable in this approach is the domestic interest rate. The theory indicates that we wish to use the most market determined rate. In the Korean case, the 90 day CD rate would be an ideal series (World Bank, 1993); however, reporting of this series only begins in $1991 .^{7}$ Two of the other candidate time series for Korean interest rates are illustrated in Figure 1. One is the corporate bond rate (IKO3) since this series is available for a long time period and is freer of government intervention than some other the other rates (see Kang, 1993). The second rate is the overnight call money rate (IMMKO). Since the latter is available for a longer span, and does not conflate differing maturities, we rely on the latter series. In an earlier version of this paper, the corporate bond rate was used, and produced a similar break-point. ${ }^{8}$

${ }^{6}$ The EuroYen and EuroDollar rates are London close end-of-period 3 month Eurocurrency deposit rates; arithmetic average of bid and ask rates provided by Data Resources, Inc.. LIBOR is the monthly average of 3 month LIBOR and is provided by the World Bank.

${ }^{7}$ Personal communication with Jae Sung Hur, New York Representative Office of the Bank of Korea, November 17, 1995.

${ }^{8}$ That version also discussed the use of other commonly reported rates, including the 3 month investment and finance company rate and the Monetary Stabilization Bond rate. Both of these series have been reported by Morgan Guaranty as the money market rate at various times. 
The Taiwanese case is complicated since its banking sector has been highly regulated over most of its history and a large proportion of total credit is issued in the unofficial curb market. We considered two series, the curb market and the 90 day banker's acceptance rate (ITI). This latter rate is plotted in Figure 2. The curb market rate is often used as a proxy for the free market rate (as in Reisen and Yèches, 1993). However, the curb rate represents the interest rate on marginal demand not satisfied by the formal regulated market, and incorporates a time-varying risk premium due to the unsecured nature of the debt. Since we do not wish to model the risk premium on informal loans, we focus on results using the 90 day banker's acceptance rate. ${ }^{9}$

The choice of the EuroYen rate, instead of either the EuroDollar rate or LIBOR may strike some readers as odd. We select this rate because it is well known that both countries peg to the US dollar; in using the EuroYen rate, we bias the case against finding a correlation between the foreign and domestic rates. When a correlation is found, our case is that much the stronger. It turns out that using other rates yields similar results in terms of the estimated breaks (see Section 4, below).

\subsection{PRELIMINARY DATA ANALYSIS}

Notice that because of the linearity in equation (4), one could integrate up to obtain a

However, the latter rate is substantially influenced by the government, while the latter, until recently, was explicitly regulated. IKO3 was provided in personal communication with Bong Sung Oum, IMMKO is from the international financial statistics.

9 The two series move together very closely, especially in the later portion of the sample period. The regression of the level of the bankers' rate on the curb market rate yields a coefficient of 1.08 , and an $R^{2}$ of 0.93 . In differences, the coefficient is 074 , with a $R^{2}$ of 0.73 . ITI is from the Morgan Guarantee database, ICTI from the Republic of China Financial Statistics Monthly. 
relationship between the level of the interest rate, and the levels of the right hand side variables. This specification (augmented by a deterministic time trend) would be appropriate if all the series were trend stationary, or alternatively, if they were all cointegrated. We therefore conduct a preliminary analysis of both the Korean and Taiwanese data, using the standard tests for unit roots and co-integration. The results, (available on request), indicate that most series fail to reject the null hypothesis of a unit root, using an Augmented Dickey-Fuller test, with constant and trend

Proceeding under the presumption that all the series contain unit roots, we test for cointegration, i.e., the possibility that the series contain common stochastic trends. The EngleGranger test for cointegration fails to reject the null hypothesis of no cointegration in both cases. In fact, the ADF statistics are nowhere near even the $10 \%$ critical values. Hence, we estimate the model in a first differences rather than an error correction specification, with one exception described in Section 4.2, which serves to reinforce our conclusions.

\subsection{ECONOMETRIC METHODOLOGY}

Finding the "correct" model is not essential so long as the explanatory variables explain a substantial fraction of the total variance and are orthogonal to the error term. In principle there is a tradeoff between parsimony and potential for mis-specification. Hence, we include lags up to the last one that is significant. This means there are a number of statistically insignificant coefficients.

While in theory there are feedback equations relating the right-hand-side variables to the domestic interest rate, it is doubtful that the effects are instantaneous (or within-the-month), so 
for the most part, the right-hand-side variables can be taken as predetermined. The one possible exception is the change in domestic credit, which the central bank presumably can quickly change in response to changes in the interest rate. In principle one could jointly estimate a central bank reaction function with equation (4). Since such functions are notoriously unstable (McNees, 1992), we undertake a less ambitious approach, and test to see whether the right-hand side variables can be taken as exogenous or at least predetermined. Hence a series of Wu-Hausman (exogeneity) tests are conducted for the domestic credit variable, which appears most likely to be endogenous.

The model could be estimated using a Kalman filter technique for obtaining time-varying parameters. However, studies using this technique frequently find it difficult to calculate standard errors and must rely on somewhat ad hoc techniques for detecting structural break in the varying parameters. As examples, both Reisen and Yèches (1993) and Jwa (1994) use a constant confidence interval derived from fixed coefficient estimates in their graphical analysis, despite the reductions in standard errors that occur as more observations are incorporated to update parameters. This can lead to spuriously detecting breaks early in sample and incorrectly rejecting break later. To ensure the robustness of our tests for structural break, we therefore use OLS and recursive OLS and then employ multiple graphical and statistical procedures to test the stability of the model over the sample period:

1. The graph of one-step-ahead Chow tests asks if parameter constancy can be rejected given a one-step forecast with progressively longer base sample period.

2. Recursive parameter estimates update using the information from each additional observation and allow testing for individual parameter stability. 
3. The Standard Chow test generated by fitting the model to both sub-periods independently and comparing the Residual Sum of Squares of the constrained and unconstrained sub-periods

Although straightforward, this more robust econometric approach applied to the correctly specified interest rate equation as derived in section 2 is likely to yield results in which we can have a high degree of confidence.

\section{EMPIRICAL RESULTS}

\subsection{KOREA}

The first column of Table 1 presents a stable specification of the determinants of the Korean interest rate for the 1983:06-1989:01 period. The industrial production variable enters significantly in one case, and the sum of the coefficients is positive as expected. Although only one of the domestic credit lags is statistically significant, it has the correct sign, as does the sum of the coefficients. The ex post rational expectations proxy for inflationary expectations entered significantly, although the contemporaneous rate entered more so, and of larger value. Hence results using the backward looking proxy are presented. ${ }^{10}$ The foreign rate of retum is also included. It appears insignificant and of the incorrect sign. This result would be expected if the local financial market is well insulated from the world market by capital controls. The specification appears to pass the diagnostics for serial correlation, heteroskedasticity, ARCH,

${ }^{10}$ The apparent superiority of the backward looking proxy could be due to the large amount of measurement error associated with using an ex post measure, especially when using realized one month inflation rates. 
normality, and omitted variables (the Ramsey RESET test). The specification also passes the CUSUM and CUSUM-squares tests.

Results for the same specification for the entire sample (1983:06 to 1994:09) are given in the second column. Several of the domestic variables drop in both economic and statistical significance; only the first lag of industrial production, and the first two lags of domestic credit, enter in more significantly and at a significant level. In contrast, the EuroYen rate now becomes a more important, and correctly signed, determinant of local interest rates, statistically significant at the $5 \%$ level.

Inspection of the actual and fitted series (Figure 3), the recursive estimates for the coefficients (available on request, as well as the Chow 1-step-ahead forecast error F-test, confirm that a dramatic break occurred sometime between 1989:01 and 1989:02 (see Figure 4). These conclusions are reinforced by the results from the recursive coefficient estimates which further indicate that the break was due to an increase in capital mobility: The coefficients on industrial production, the trade balance, domestic credit and the seasonal dummies all become less significant and move toward zero, while the EuroYen coefficient shows a clear movement toward both greater economic and statistical significance."

Finally, column 3 presents results for a reasonable post-break specification, where the EuroYen rate enters significantly. The coefficient suggests that over $100 \%$ of any innovation in the foreign rate is passed through to domestic rates, although the one standard bounds encompass the value of unity. Industrial production lagged one and six months, domestic credit lagged one

1 Application of the Wu-Hausman test $(\mathrm{Wu}, 1973)$ indicates some endogeneity of the first lag of domestic credit, perhaps explaining why this coefficient does not exhibit a clear change in value over the two regimes. 
month, and two seasonal dummies enter significantly, implying that the capital account is still not perfectly open.

Overall, the results very strongly indicate a break in how interest rates were determined after 1989:01. While this outcome could be caused by any number of domestic financial reforms, the fact that the recursive estimates for most of the domestic factors and dummies moved toward zero argues persuasively that a significant element of the break was due to a greater openness to the world market.

It is important to observe that the break-point results are not very sensitive to the use of particular measures of local or foreign interest rates. The estimated break points, using $1 \%$ MSLs, for various combinations of domestic interest rates (IKO3 and IMMKO) versus foreign returns (IEJP, IEUS, LIBOR) all occur around the end of 1988 or early $1989 .{ }^{12}$

These results contrast strongly with previous studies that use Kalman filtering for estimating time-varying parameters. Reisen and Yèches (1993) identify an opening in mid-1984, with openness subsequently declining. Jwa (1994) finds the opening starting in mid-1985, with a reduction in openness in 1988 , and a temporary re-opening in 1989 . The studies differ in how they measure the foreign return. The first paper incorporates ex post depreciation in their foreign return, while the second uses an $\operatorname{ARIMA}(1,1,0)$ prediction to model the future spot rate. Interestingly, Dooley and Mathieson (1994), using the same economic methodology but recursive OLS regressions, detect no structural breaks over their sample up to 1988 , lending indirect support for our findings.

${ }^{12}$ The regressions using IKO3 and IEJP,IEUS or LIBOR all break in 1988:12 and 1989:01. Using IMMKO on IEUS or LIBOR showed break in 1989:02. 


\subsection{TAIWAN}

The story that emerges for Taiwan is one of a capital account that remained relatively closed until at least early 1989. Column 1 in Table 2 presents a reasonable specification for the period 1983:07 to 1989:03 that passes the diagnostic tests, except for ARCH effects. The foreign interest rate is again insignificant as would be expected if domestic capital markets were still insulated from outside influences. Domestic credit, lagged three months, as well as the current account at lags three through five, are significant, while the other domestic economic determinants are not. Together with ten seasonal dummy variables, the domestic factors appear to explain over $50 \%$ of the variation in the interbank rate.

Once the sample is expanded to include data up to 1994:11, several of the domestic and seasonal dummy coefficients become significant and with correct sign. However, domestic credit at lag two becomes statistically significant, with incorrect sign. On the other hand, the EuroYen rate becomes statistically significant, and of correct sign. The graphs of actual and fitted values and the 1-step-ahead forecasts in Figures 5 and 6 corroborate the very strong results of both the Chow tests indicating that there was a dramatic structural break around 1989:04. ${ }^{13}$ As in the Korean case, the recursive parameter estimates (available on request) suggest that part of this break was due to the opening up of the capital account: The foreign rate coefficient jumps dramatically in significance and magnitude while the domestic variable coefficients that were significant in the pre-break period move towards zero.

In the third column, a reasonable post-break specification is presented. While only four

${ }^{13}$ Regressions using ICTI and IEJP or ITI on IEUS showed break in 1989:04. Using ITI on LIBOR showed break in 1986:04. 
domestic economic variables show up with any statistical significance, the EuroYen rate coefficient shows up as statistically significant. Furthermore, a specification that passes the diagnostic battery is only obtained when a lagged error correction term, incorporating the difference between the local and EuroYen rate, is included. The coefficient on this term is statistically significant. This last finding is consistent with the finding of cointegration between domestic and foreign interest rates during the later subsample. ${ }^{14}$ This finding of a break is at variance with those obtained by Reisen and Yèches (1993).

\subsection{INTERPRETATION}

It would be ideal to match the estimated structural breaks with coinciding policy reforms. Since studies of the Korean and Taiwanese liberalizations have been conducted by others in some detail, ${ }^{15}$ this paper will not attempt to offer more detail than they have provided. However, what emerges from a brief overview of the two countries' experiences is a pattern of uneven and tentative reforms, that have been implemented and sometimes reversed as macroeconomic conditions dictate.

Korea: Throughout the 1980 's, Korea imposed restrictions on foreign holdings of many types of financial instruments in an attempt to maintain domestic control over monetary policy. These restrictions were eased only in the face of massive current account surpluses over the

14 The Engle-Granger statistic (for a regression with a trend, and one lag of the first differences) is 4.90 , while the $1 \%$ critical value is 4.57 . Cointegration is not found for the entire period. Similar, albeit weaker, results are obtained for Korea; hence a similar error correction term is not included in the Korea post-break regressions.

${ }^{15}$ See Frankel (1991), Lindner (1992) for Korea; Chiu and Hou (1993), Chang (1990), Kuo (1990) and Emery (1988) for Taiwan; Moreno (1993) and Jwa (1994) for both. 
1986-89 period which induced rapid monetary growth. The response included moderation of the restrictions on financial institutions and individuals foreign borrowing and lending which are detailed in Moreno (1993).

Many measures were implemented in the months around the break period of late 1988 or early 1989 , although none of them obviously explains the break. The prime candidate includes the reforms of the domestic financial system in December 1988, when lending rates, deposit rates and money market instruments were liberalized. ${ }^{16}$ Moreover, in November, Korean residents were granted automatic approval for overseas investment up to US\$ 2 million, and the limit on export of Korean currency notes was raised from 5,000 won to 2 million won. Also in that month, Korea formally accepted the obligations of Article VIII, Sections 2-4 of the IMF's Articles of agreement. This move required Korea to eliminate its remaining restriction on payments and transfers for current account transactions (Lindner, 1992: 5). In January of 1989, further restrictions imposed on unregistered inflows of foreign exchange which were subsequently undone in December. No new significant reforms of the external sector appear until January of 1990 , long after the period of break. ${ }^{17}$ Hence, the problem seems not to be a dearth of candidate explanations, but rather a surfeit.

Taiwan: Like Korea, Taiwan traditionally restricted capital outflows, but was prompted by massive accumulation of foreign reserves to undertake some liberalizing measures. Again, it is difficult to isolate a particular measure that would explain the observed break around April

${ }^{16}$ The actual impact of these measures is somewhat in doubt, according to Frankel (1991) and Jwa (1994: 138), although Tseng and Corker (1991: 39) term them "significant".

17 At this time, the ceiling on foreign investment subject to automatic approval is raised to US\$100 million from the US\$3 million level. 
of 1989.

In June 1988, foreign banks were permitted to join the local interbank remittance system. In July, current account transactions were completely liberalized and requirements to surrender export proceeds, advanced import deposits and restrictions on payments for invisible were lifted. Individuals or enterprises were permitted to purchase and remit outward up to US\$ 5 million annually. A ceiling for inward remittances was set at US\$50,000 annually and would be raised to US $\$ 200,000$ in July 1989 and then to US\$500,000 in September and finally to US\$ 1 million in November of that year. In August, a foreign interbank call loan market was established.

Although the exact timing of the break could be a few months on either side of April 1989 , none of the reform measures seem to have occurred around that time leaving the exact cause still unidentifiable. In fact, a closer inspection of the data (see Figure 2) reveals that the break point coincides with initiation of a tight monetary policy aimed at bursting the stock market bubble (FEER, 1990: 232). This gives rise to at least two possible interpretations of the break. First, the extraordinary measures taken by the central bank, and not included in the regression, would have decreased the influence of formerly important factors and thus showed up as a structural break at the same time that a perhaps unrelated upward movement in the EuroYen rate makes that variable seem, temporarily, to gain in explanatory power. The break thus, does not indicate increased integration. Second, the financial markets are indeed more integrated but the statistical relation is obscured by the central bank's actions. While the domestic interest rate enters a new phase of high volatility, the EuroYen rate continues to move with much less volatility. Thus short run comovements (which are detected by regressing the first difference of the Taiwanese rate on the first difference of the EuroYen rate) are not apparent but long run 
comovements should still appear. As indicated before, a bivariate cointegration test indicates that the two interest rates are borderline cointegrated during the post-break period. This finding, combined with the failure to find cointegration over the entire period lends additional support for the second explanation, and for the contention that there was an increased degree of financial openness in the post break period.

\section{CONCLUSIONS}

This paper has applied a simple econometric model to evaluate whether the restrictions on capital flows in Korea and Taiwan have been significantly loosened over the 1980's. Our results show that there were structural breaks in the respective interest rate equations. The movements of individual parameter estimates suggest that these breaks were due to increased financial integration. In contrast to the results obtained by Reisen and Yèches (1993) and Jwa (1994), we find that the effect of the changes persists until the end of 1991. We do have difficulty in matching these statistical shifts to specific reforms of either a regulatory or policy nature. In Korea, we find several measures taken that could be responsible and believe that financial capital markets are now more integrated than they were prior to November 1988 . In Taiwan, we speculate that although measures to liberalize were taken, the dramatic break we detect is related to an increased volatility induced by the central bank. However, increased evidence of cointegration of the domestic and foreign interest rates after the break suggests that there was, nonetheless, closer integration with world financial markets over this later period.

This process of integration has important implications for the conduct of monetary policy. In the context of the standard Mundell-Fleming model, as financial capital mobility increases, managing a pegged or targeted exchange rate becomes increasingly inconsistent with an 
independent monetary policy, since sterilization of capital inflows through sales of securities becomes more costly. As Glick and Moreno (1994) point out, sterilization is slightly easier if the government can force the private sector banks to hold securities, which is what both Korea and Taiwan have done. However, as sectors of the domestic capital markets become highly integrated with the rest of the world, maintaining a banking sector that can be thus regulated becomes increasingly untenable. Hence the ultimate result of continuing liberalization is the loss of monetary autonomy, as long as these governments wish to manage their exchange rates. ${ }^{18}$

\footnotetext{
${ }^{18}$ Further discussion of this issue can be found in Frankel (1994), and Chinn and Dooley (1995).
} 


\section{REFERENCES}

Aliber, Robert Z., "The Interest Rate Parity Theorem: A Reinterpretation," Joumal of Political Economy, November -December 1973, 1451-59.

Chang, Chi-cheng, "Financial Liberalization in the Republic of China,"in S. Ghon Rhee and Rosita P. Chang, eds., Pacific-Basin Capital Mankets Research, 1990.

Chinn, Menzie and Michael Dooley, "Asia-Pacific Capital Markets: Measurement of Integration and the Implications for Domestic Financial Fragility," forthcoming in Takatoshi Ito and Anne O. Krueger,eds., Multilateralism versus Regional Trading A rnangements, Chicago:Chicago U. Press for NBER, 1995. Also NBER Working Paper \#5280.

Chinn, Menzie D. and Frankel, Jeffrey A., "Capital Barriers in the Pacific Basin: 1982-1992," Joumal of Economic Integration, March 1994a, 62-79.

and , "Financial Links around the Pacific Rim: 1982-1992," in R. Glick and M. Hutchison, eds., Exchange Rate Policy and Interdependence: Perspectives from the Pacific Basin, Cambridge: Cambridge University Press, $1994 \mathrm{~b}$.

Chiu, Paul C. H. and Hou, Teh-Chian, "Prices, Money and Monetary Policy Implementation under Financial Liberalization: The Case of Taiwan," in H. Reisen and B. Fischer, eds., Financial Opening: Policy Issues and Experiences in Developing Countries, Paris: OECD, 1993.

Dickey, David A. and Fuller, Wayne A., "Distribution of the Estimators for Autoregressive Time Series With a Unit Root," Joumal of the A merican Statistical A ssociation, June 1979, 1057-1072.

Dooley, Michael P. and Mathieson, Donald J.,"Exchange Rate Policy, Financial Structure, and the Transition from Credit to Monetary Instruments," in R. Glick and M. Hutchison, eds., Exchange Rate Policy and Interdependence: Perspectives from the Pacific Basin, Cambridge: Cambridge University Press, 1994.

Edwards, Sebastian, and Khan, Mohsin S., "Interest Rate Determination in Developing Countries: A Conceptual Framework." IMF Staff Papers, September 1985, 377-403.

Emery, Robert F., "Monetary Policy in Taiwan, China," in Hang-Sheng Cheng, ed., Monetary Policy in Pacific Basin Countries, Boston: Kluwer Academic Press, 1988.

Engle, Robert F. and Granger, C.W.J., "Co-integration and Error Correction: Representation, Estimation, and Testing." Econometrica, March 1987, 252-276.

Far East Economic Review, A sia Yearbook 1990, 1990. 
Faruqee, Hamid, "Dynamic Capital Mobility in Pacific Basin Developing Countries: Estimation and Policy Implications," IMF Staff Papers, September 1992, 706-717.

Frankel, Jeffrey, "Sterilization of Money Inflows: Difficult (Calvo) or Easy (Reisen)?" paper presented at conference on "Capital Inflows: Size, Nature and Policy Adaptations," Cartagena, Colombia, July 29-30, 1994.

Frankel, Jeffrey, "Liberalization of Korea's Foreign Exchange Markets, and the Role of U.S. Trade Relations," mimeo, Berkeley: University of California, 1991.

Glick, Reuven and Moreno, Ramon, "Capital Flows and Monetary Policy in East Asia,"in Hong Kong Monetary Authority, ed., Monetary and Exchange Rate Management with International Capital Mobility, Hong Kong, 1995 and Pacific Basin Working Paper Series PB94-08, San Francisco: Federal Reserve Bank of SF, November 1994.

Haque, Nadeem U., and Montiel, Peter, "Capital Mobility in Developing Countries -- Some Empirical Tests," IMF Working Paper \#117, December 1990.

Jwa, Sung Hee, "Capital Mobility in Korea since the Early 1980s: Comparison with Japan and Taiwan," in Takatoshi Ito and Anne Krueger, eds, Macmeconomic Linkage: Savings, Exchange Rates, and Capital Flows, NBER-East Asia Seminar on Economics Volume 3, Chicago: Univ. of Chicago Press for NBER, 1994.

Kang, Moon-Soo, "Monetary Policy Implementation under Financial Liberalisation: The Case of Korea," in Helmut Reisen and Bernard Fischer, eds., Financial Opening: Policy Issues and Experiences in Developing Countries, Paris:OECD, 1993.

Kim, Sun Bae, "Do Capital Controls Affect the Response of Investment to Savings? Evidence from the Pacific Basin, Economic Review, Federal Reserve Bank of San Francisco, 1993, 23-39.

Kouri, Pentti J.K. and Michael G. Porter, 1974, "International Capital Flows and Portfolio Equilibrium," Joumal of Political Economy, May-June 1974, 443-467.

Kuo, Shirley W. Y.,"Liberalization of the Financial Market in Taiwan in the 1980's," in S. Ghon Rhee and Rosita P. Chang, eds., Pacific-Basin Capital Markets Research, 1990.

Lindner, Deborah, "Foreign Exchange Policy, Monetary Policy, and Capital Market Liberalization in Korea," Intemational Finance Discussion Papers \#435, 1992.

McNees, Stephen, "A Forward-Looking Monetary Policy Reaction Function: Continuity and Change, "New England Economic Review, November-December 1992, 3-13.

Maloney, William F., "Testing Capital Account Liberalization without Forward Rates: Another Look at Chile, 1979-82," Joumal of Development Economics, forthcoming. 
Moreno, Ramon, "Exchange Rate Policy and Insulation from External Shocks: The Experience of Taiwan and Korea: 1970-1990," Working Paper 93-05, Center for Pacific Basin Monetary and Economic Studies, Federal Reserve of San Francisco, 1993.

Reisen, Helmut and Hélèn Yèches, "Time-varying Estimates on the Openness of the Capital Account in Korea and Taiwan." Joumal of Development Economics, August 1993, 285-305.

Tseng, Wanda and Robert Corker, Financial Liberalization, Money Demand, and Monetary Policy in A sian Countries, Occasional Paper 84, Washington, DC:IMF, 1991.

World Bank, Korea Financial Sector Study, Report No. 11373-KO, Industry and Energy Operations Division, Country Dept. I, East Asia and Pacific Regional Office, July 1993.

Wu, D.-M., "Alternative Tests of Independence between Stochastic Regressors and Disturbances," Econometrica, July 1973, 733-50. 
Table 1

Korea: Ovemight Call Money Rate

\begin{tabular}{|c|c|c|c|}
\hline Coefficient & $1983: 06-89: 01$ & $1983: 06-94: 09$ & $1983: 06-94: 09$ \\
\hline const. & -0.047 & 0.196 & 0.084 \\
\hline$\Delta \mathrm{R}^{\mathrm{JP}}$ & $\begin{array}{l}(0.26) \\
0.037 \\
(0.17)\end{array}$ & $\begin{array}{l}(1.01) \\
0.692^{\star \star} \\
(2.18)\end{array}$ & $\begin{array}{l}(0.35) \\
1.613^{\star} \\
(2.64)\end{array}$ \\
\hline$\Delta y(-1)$ & 2.029 & $5.837^{\star}$ & $\begin{array}{l}4.790 \\
(0.95)\end{array}$ \\
\hline$\Delta y(-2)$ & -0.360 & & 6.012 \\
\hline$\Delta y(-3)$ & $4.187 *$ & -1.602 & $\begin{array}{l}(1.06) \\
-2.291\end{array}$ \\
\hline$\Delta y(-4)$ & $(1.81)$ & & $\begin{array}{l}(0.37) \\
9.392 \\
(1.48)\end{array}$ \\
\hline$\Delta y(-5)$ & & & \\
\hline$\Delta y(-6)$ & & & \\
\hline & $\begin{array}{l}1.420 \\
(0.25)\end{array}$ & $\begin{array}{l}-12.197 * \\
(1.76)\end{array}$ & $\begin{array}{l}-30.629 * * * \\
(3.67)\end{array}$ \\
\hline & $\begin{array}{l}-1.339 \\
(0.21)\end{array}$ & $\begin{array}{l}-12.737^{\star} \\
(1.67)\end{array}$ & -12.705 \\
\hline & $\begin{array}{l}-4.904 \\
(0.69)\end{array}$ & $\begin{array}{l}-7.949 \\
(1.06)\end{array}$ & \\
\hline & $\begin{array}{l}9.616 \\
(1.54)\end{array}$ & $\begin{array}{l}4.722 \\
(0.60)\end{array}$ & \\
\hline$\Delta d c(-5)$ & $\begin{array}{l}-29.985 * \star \star \\
(4.27)\end{array}$ & -11.328 & \\
\hline$\Delta \mathrm{dc}(-6)$ & $\begin{array}{l}-4.138 \\
(0.70)\end{array}$ & $\begin{array}{l}2.049 \\
10.433\end{array}$ & \\
\hline$C A(-1)$ & $\begin{array}{l}0.005 \\
(0.22)\end{array}$ & $\begin{array}{l}-0.380 \\
(1.22)\end{array}$ & \\
\hline$C A(-2)$ & $\begin{array}{l}-0.205 \\
(0.91)\end{array}$ & $\begin{array}{l}-0.127 \\
(0.43)\end{array}$ & \\
\hline$C A(-3)$ & $\begin{array}{l}-0.338 \\
(1.43)\end{array}$ & $\begin{array}{l}0.425 \\
(1.35)\end{array}$ & \\
\hline$C A(-4)$ & $\begin{array}{l}0.413^{\star} \\
(1.78)\end{array}$ & $\begin{array}{r}-0.175 \\
(0.57)\end{array}$ & \\
\hline$\Delta \pi$ & $\begin{array}{l}0.004 \\
(0.45)\end{array}$ & $\begin{array}{l}0.000 \\
(0.00)\end{array}$ & $\begin{array}{l}0.022 \\
(0.89)\end{array}$ \\
\hline s2 & $0.597^{*}$ & 0.595 & \\
\hline s4 & $0.658 * \star$ & 0.287 & \\
\hline s5 & $\begin{array}{l}0.558^{\star} \\
(1.74)\end{array}$ & $\begin{array}{l}0.269 \\
(0.57)\end{array}$ & \\
\hline
\end{tabular}




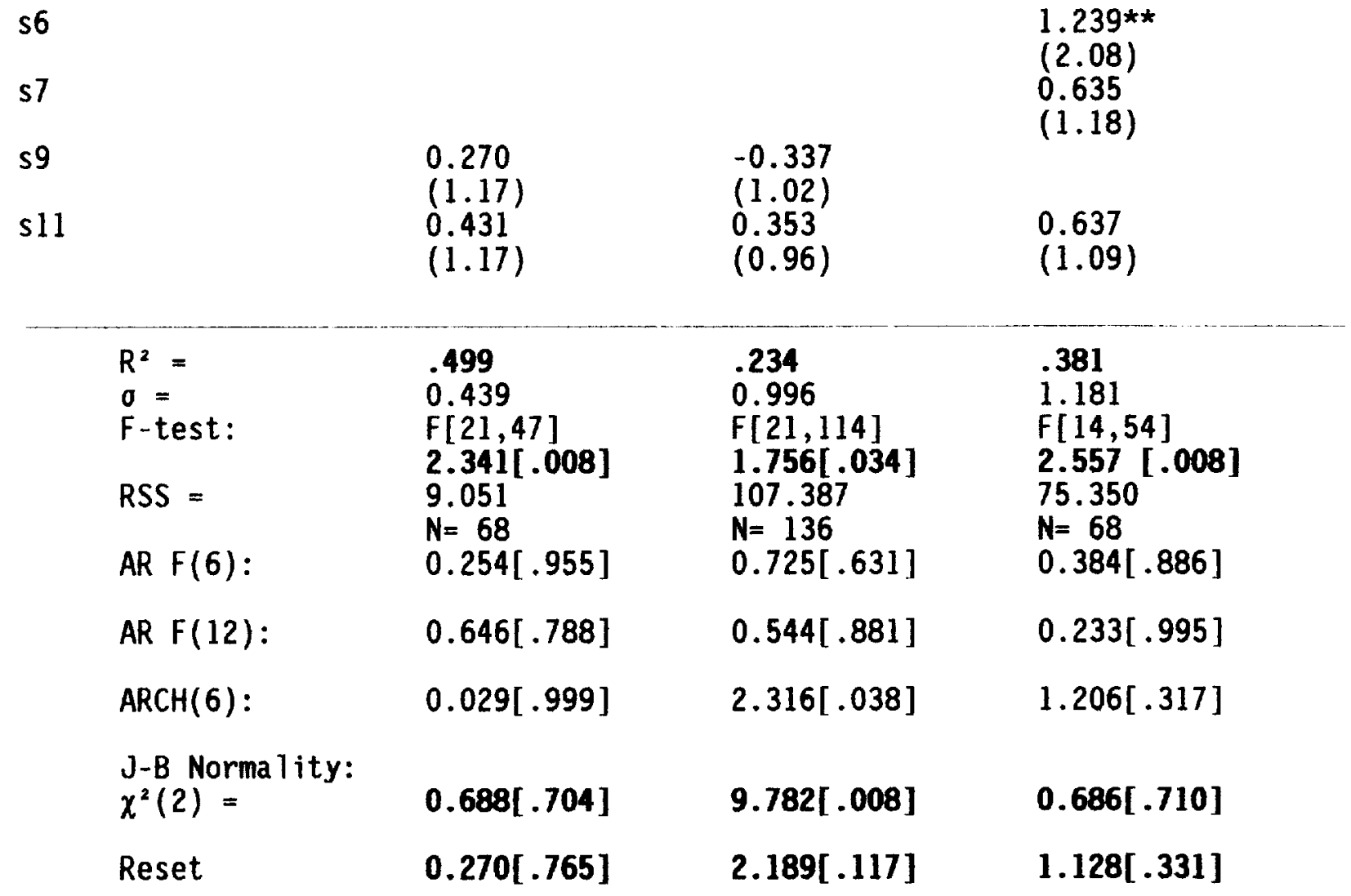

Tests of Parameter Constancy

Tests of parameter constancy estimated with the 1983:06-1989:01 sample over the period 1989:02 - 1994:09

Chow LR test: 1.319 [.343]

Chow forecast test: $7.510[.000]$

Notes: $P$-values in brackets, $t$-statistics in parentheses. $a=$ standard error, $D W=$ Durb in Watson, $R S S=$ residua 1 sum of squares, $A R F(j)=L M F$-test for residual auto-correlated from lags $1-j, A R C H=L M F-t e s t$ for autoregressive conditional heteroskedasticity, $J-B=J a r q u e-B e r a$ test for normality, Reset=regression specification $F$-test for omitted variables. Current account coefficients multiplied by 1000 . 
Table 2

Taiwan: 90 Day Interbank Rate

\begin{tabular}{|c|c|c|c|}
\hline Coefficient & $1983: 06-89: 03$ & $1983: 06-94: 10$ & $1989: 04-94: 10$ \\
\hline const. & 0.498 & -0.045 & 0.293 \\
\hline$\Delta R^{J P}$ & $\begin{array}{r}-0.145 \\
(0.62)\end{array}$ & $\begin{array}{l}0.673^{\star *} \\
(1.94)\end{array}$ & $\begin{array}{l}1.746^{\star \star * *} \\
(3.03)\end{array}$ \\
\hline$\Delta y(-1)$ & $\begin{array}{l}-2.226 \\
(1.08)\end{array}$ & $\begin{array}{l}0.892^{\star} \\
(0.41)\end{array}$ & \\
\hline$\Delta y(-2)$ & $\begin{array}{l}-2.588 \\
(1.06)\end{array}$ & $\begin{array}{l}-2.240 \\
(0.78)\end{array}$ & \\
\hline$\Delta y(-3)$ & $\begin{array}{l}2.187 \\
(0.82)\end{array}$ & 0.786 & \\
\hline$\Delta y(-4)$ & $\begin{array}{l}-0.687 \\
(0.27)\end{array}$ & $4.943^{*}$ & \\
\hline$\Delta y(-5)$ & $\begin{array}{l}1.451 \\
(0.78)\end{array}$ & $\begin{array}{l}3.794^{\star} \\
(1.74)\end{array}$ & \\
\hline$\Delta d c(-1)$ & $\begin{array}{r}-5.665 \\
(1.11)\end{array}$ & $\begin{array}{l}7.915 \\
(1.21)\end{array}$ & $\begin{array}{l}25.793 * * * \\
(2.66)\end{array}$ \\
\hline$\Delta \mathrm{dc}(-2)$ & & $\begin{array}{l}12.017^{\star *} \\
(1.97)\end{array}$ & $\begin{array}{l}34.621^{\star \star * *} \\
(4.33)\end{array}$ \\
\hline$\Delta d c(-3)$ & $\begin{array}{l}10.796 * \\
(1.87)\end{array}$ & $\begin{array}{l}8.168 \\
(1.28)\end{array}$ & $\begin{array}{l}22.580^{* \star \star *} \\
(2.84)\end{array}$ \\
\hline $\mathrm{CA}(-1)$ & $\begin{array}{l}-0.007 \\
(0.69)\end{array}$ & $\begin{array}{l}0.002 \\
(0.16)\end{array}$ & $\begin{array}{l}-0.012 \\
(0.83)\end{array}$ \\
\hline$C A(-2)$ & $\begin{array}{l}0.006 \\
(0.65)\end{array}$ & $\begin{array}{l}0.014 \\
(1.26)\end{array}$ & $\begin{array}{l}0.024 \\
(1.50)\end{array}$ \\
\hline$C A(-3)$ & $\begin{array}{l}-0.029 * * * * \\
(3.03)\end{array}$ & $\begin{array}{l}-0.006 \\
(0.59)\end{array}$ & $\begin{array}{l}-0.000 \\
(0.04)\end{array}$ \\
\hline $\mathrm{CA}(-4)$ & $\begin{array}{l}0.016^{\star} \\
(1.73)\end{array}$ & $\begin{array}{l}-0.020^{\star} \\
(1.94)\end{array}$ & $\begin{array}{l}-0.055^{* * *} \\
(3.96)\end{array}$ \\
\hline $\mathrm{CA}(-5)$ & $\begin{array}{l}0.014^{\star} \\
(1.67)\end{array}$ & $\begin{array}{l}0.017^{\star} \\
(1.64)\end{array}$ & \\
\hline$\Delta \pi$ & $\begin{array}{l}-0.009 \\
(1.29)\end{array}$ & $\begin{array}{l}-0.008 \\
(1.18)\end{array}$ & $\begin{array}{l}-0.008 \\
(0.99)\end{array}$ \\
\hline$\left[R-R^{J P}\right](-1)$ & & & $\begin{array}{l}-0.218^{\star \star \star} \\
(3.13)\end{array}$ \\
\hline $\begin{array}{l}\text { s2 } \\
\text { s3 }\end{array}$ & $\begin{array}{l}-0.247 \\
(0.61) \\
-2.148 * \star \star \\
(3.27)\end{array}$ & $\begin{array}{l}-0.092 \\
(0.19) \\
-0.867 \\
(1.45)\end{array}$ & \\
\hline s4 & $\begin{array}{l}-0.369 \\
(0.67)\end{array}$ & $\begin{array}{l}-0.530 \\
(0.98)\end{array}$ & $\begin{array}{l}-0.218^{\star \star \star \star} \\
(3.13)\end{array}$ \\
\hline s6 & $\begin{array}{l}-1.032^{\star} \\
(1.91)\end{array}$ & $\begin{array}{l}0.344 \\
(0.59)\end{array}$ & \\
\hline s7 & $\begin{array}{l}0.749 \\
(1.40)\end{array}$ & $\begin{array}{l}-0.642 \\
(1.10)\end{array}$ & \\
\hline
\end{tabular}




\begin{tabular}{|c|c|c|c|}
\hline $\begin{array}{l}s 8 \\
s 9 \\
s 10 \\
s 11\end{array}$ & $\begin{array}{l}-1.056 \star \\
(1.90) \\
-0.604 \\
(1.59) \\
-1.224 * \star \star \\
(3.35) \\
-0.659 \star \\
(1.94)\end{array}$ & $\begin{array}{l}-1.284^{\star \star} \\
(2.21) \\
-1.119 \star \star \star \\
(2.57) \\
-0.835 * \star \\
(1.97) \\
-0.864^{\star \star} \\
(2.05)\end{array}$ & \\
\hline $\begin{array}{l}\mathrm{R}^{2}= \\
\sigma= \\
\mathrm{F} \text {-test: } \\
\mathrm{RSS}= \\
\text { AR } \mathrm{F}(6):\end{array}$ & $\begin{array}{l}.528 \\
0.506 \\
F[25,44] \\
2.053[.019] \\
11.265 \\
N=69 \\
0.326[.919]\end{array}$ & $\begin{array}{l}.324 \\
1.017 \\
F[25,112] \\
2.234[.002] \\
115.750 \\
N=137 \\
2.644[.020]\end{array}$ & $\begin{array}{l}5561 \\
1.080 \\
F[18,56] \\
6.363[.008] \\
65.336 \\
N=68 \\
1.412[.229]\end{array}$ \\
\hline AR $F(12):$ & $1.015[.459]$ & $2.590[.005]$ & $0.949[.509]$ \\
\hline $\operatorname{ARCH}(6):$ & $3.732[.003]$ & $0.270[.974]$ & $1.235[.303]$ \\
\hline $\begin{array}{l}\text { J-B Norma 1 ity: } \\
\chi^{2}(2)=\end{array}$ & $0.561[.756]$ & $68.792[.000]$ & $26.293[.000]$ \\
\hline Reset & $1.277[.289]$ & $1.845[.163]$ & $0.195[.824]$ \\
\hline
\end{tabular}

Tests of Parameter Constancy

Tests of parameter constancy estimated with the 1983:07-1989:03 sample over the period 1989:04 - 1994:11

Chow LR test: $2.212[.004]$

Chow forecast test: $6.001[.000]$

Notes: P-values in brackets, $t$-statistics in parentheses. $\sigma=$ standard error, $D W=$ Durb in Watson, $R S S=$ residual sum of squares, $A R F(j)=L M F$-test for residual auto-correlated from lags $1-j, A R C H=L M F$-test for autoregressive

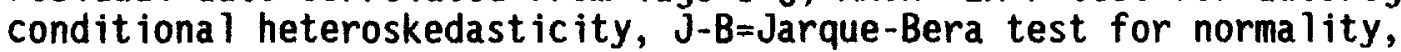
Reset=regression specification $F$-test for omitted variables. 


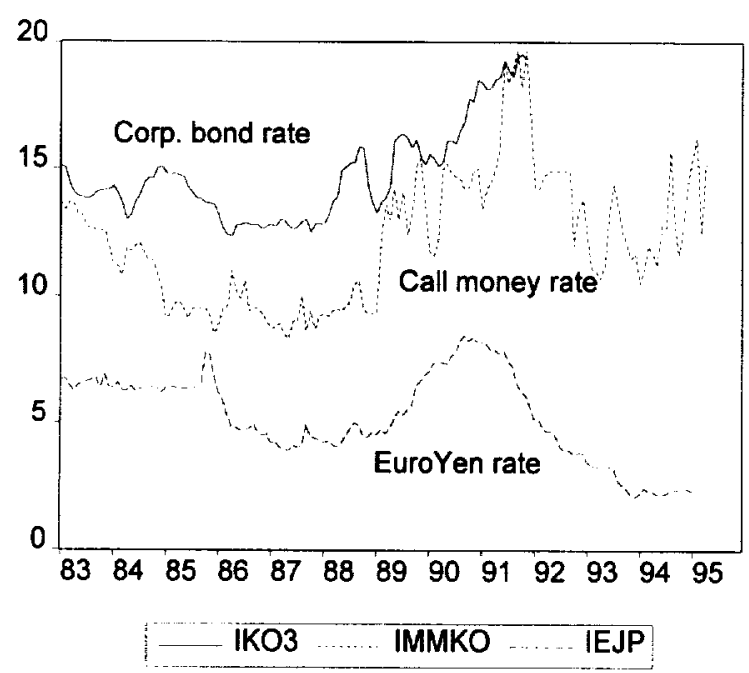

Figure 1: Korean and EuroYen Interest Rates

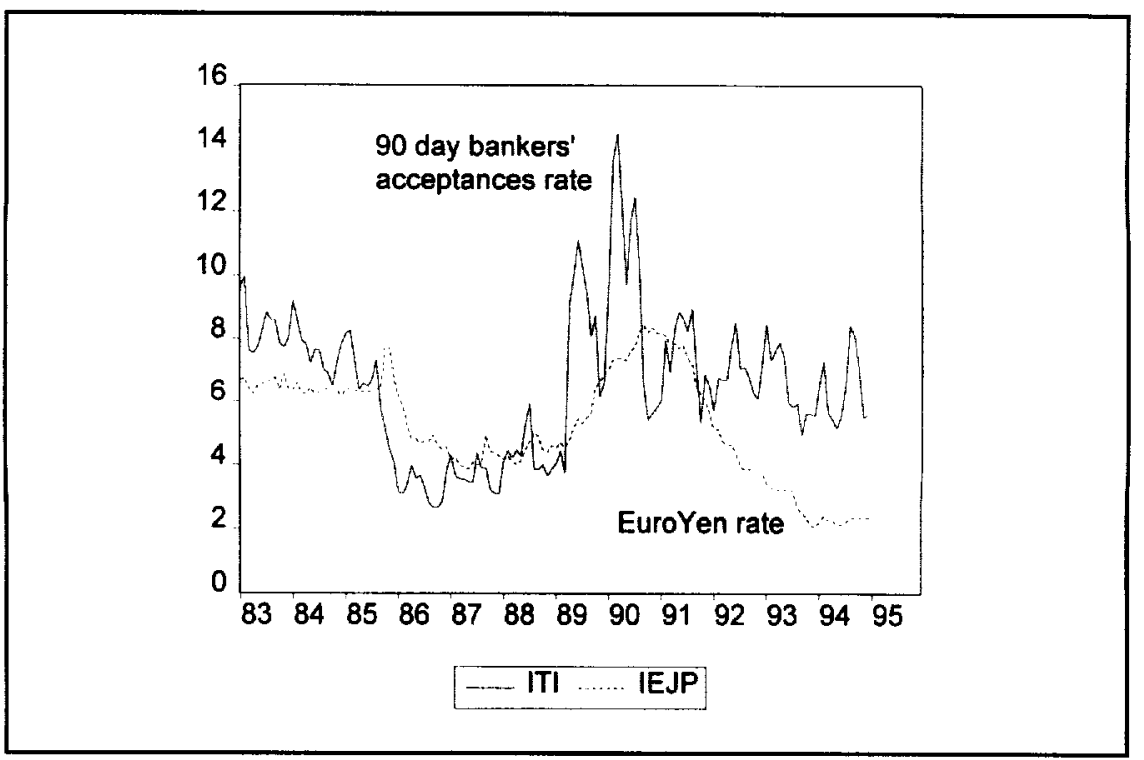

Figure 2: Taiwanese and EuroYen Interest Rates 


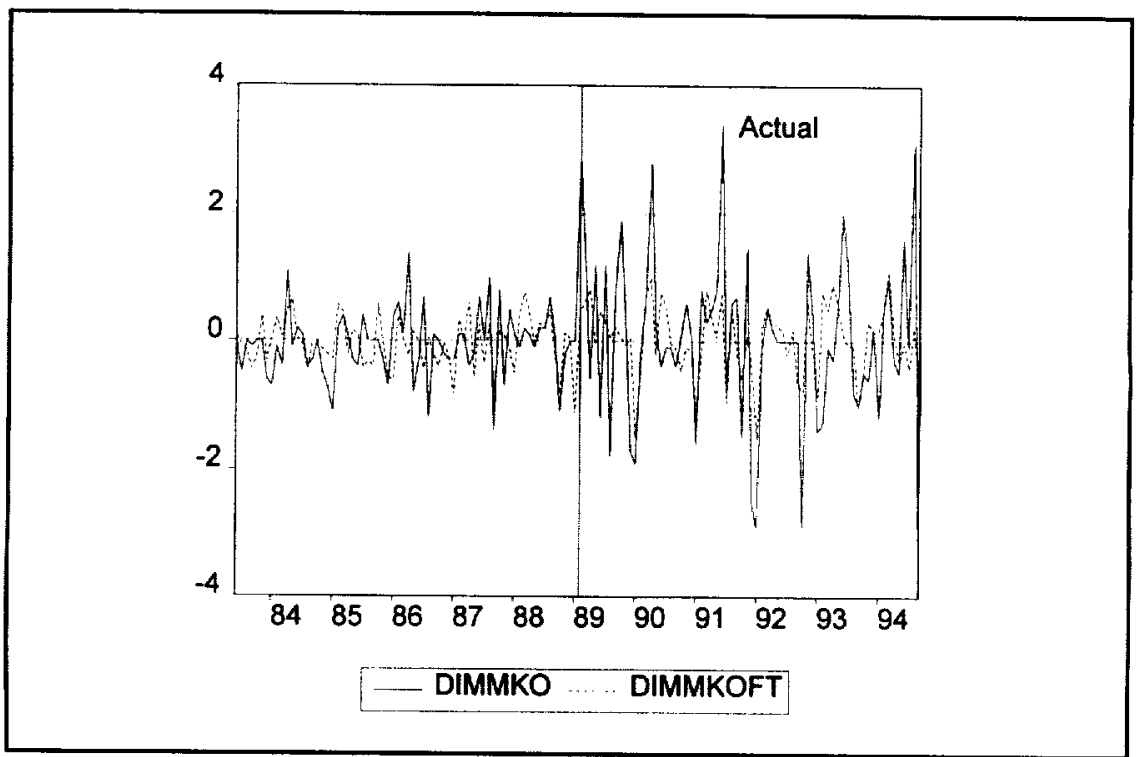

Figure 3: Actual and fitted values

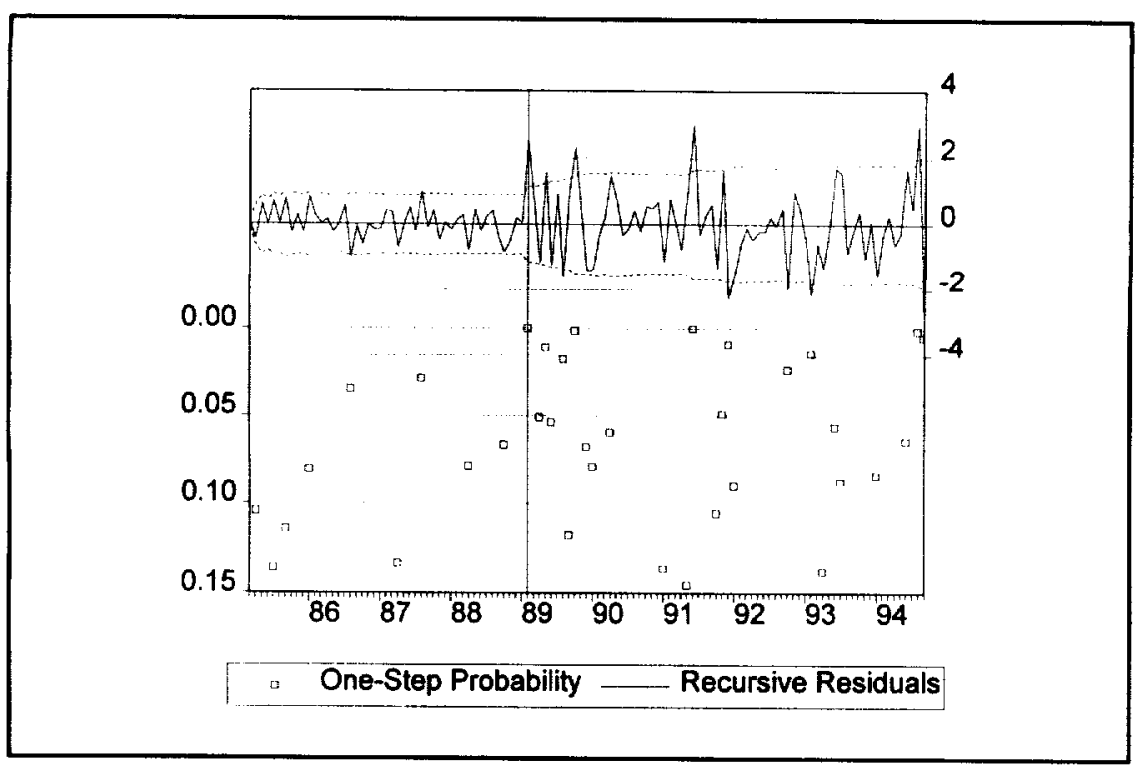

Figure 4: Recursive 1-step F-test 


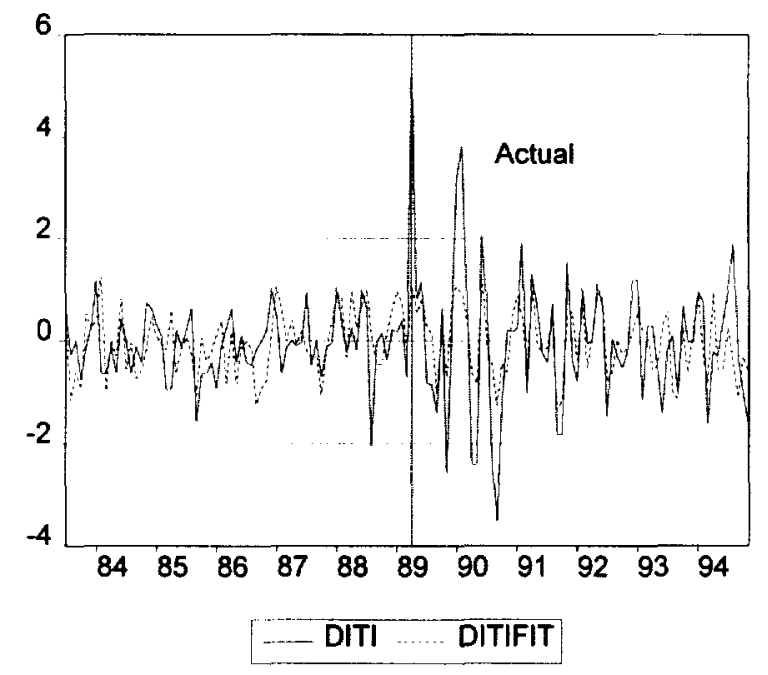

Figure 5: Actual and fitted values

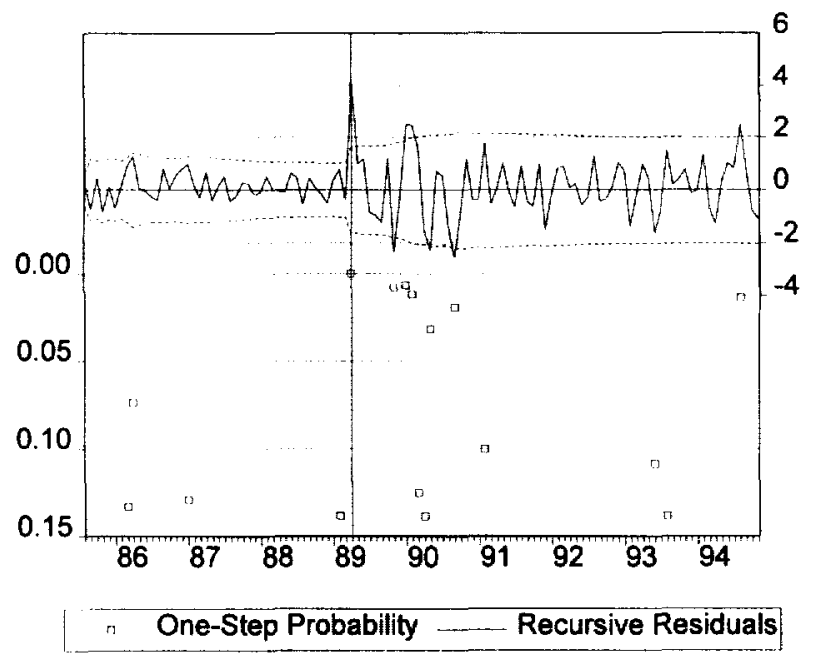

Figure 6: Recursive 1-step F-test 